\title{
PENGARUH KINERJA KEUANGAN TERHADAP RETURN SAHAM PERUSAHAAN PERTAMBANGAN
}

\author{
RONA TUMIUR MAULI CAROLIN SIMORANGKIR \\ Universitas Mercu Buana Jakarta, Jl. Meruya Selatan No.1, Kec. Kembangan, Kota Jakarta Barat, Indonesia \\ rona_caroline@mercubuana.ac.id
}

\begin{abstract}
This research aims to know the influence of return on asset, return on equity, and net profit margin on stock return. The population used Minning Company on the BEI with the observation periods during 2013 until 2017 as many as 13 companies. The source of the secondary data has been obtained from Indonesia Stock Exchange. The data analysis technique has been carried out by using multiple linear regressions analysis. Based on the result of the analysis indicate that return on asset, return on equity, and net profit margin significant effect on stock return of banking company. Based on the test results are partially, return on asset has a negative and significant effect on stock returns, return on equity and net profit margin have influence to the stock return of Minning Company.
\end{abstract}

Keywords: Stock return, return on asset, return on equity, net profit margin

\begin{abstract}
Abstrak: Penelitian ini bertujuan untuk mengetahui pengaruh return on asset, return on equity, dan net profit margin terhadap return saham. Populasi menggunakan Minning Company di BEI dengan periode pengamatan selama 2013 hingga 2017 sebanyak 13 perusahaan. Sumber data sekunder diperoleh dari Bursa Efek Indonesia. Teknik analisis data telah dilakukan dengan menggunakan analisis regresi linier berganda. Berdasarkan hasil analisis menunjukkan bahwa return on asset, return on equity, dan net profit margin berpengaruh signifikan terhadap return saham. Return on asset berpengaruh negatif dan signifikan terhadap return saham. Return on equity dan net profit margin berpengaruh positif dan signifikan terhadap return saham perusahaan minning.
\end{abstract}

Kata kunci: Stock return, return on asset, return on equity, net profit margin

\section{PENDAHULUAN}

Krisis ekonomi yang dialami oleh Indonesia pada tahun 1998 dan di tahun 2008 masih terasa sampai saat ini, sebagai contoh adalah para pengusaha yang khawatir akan perkembangan usahanya akibat dari ekonomi yang masih labil. Hal tersebut melatar belakangi masyarakat untuk mencari pendapatan lain bahkan supaya nilainya tetap bertambah. Usaha yang dilakukan oleh masyarakat salah satunya adalah deng an melakukan investasi. Investasi merupakan penundaan konsumsi saat ini untuk digunakan di dalam produksi yang efisien selama periode waktu tertentu. Investasi ini diharapkan dapat meningkat nilainya di masa yang akan datang. Berdasarkan hal tersebut investasi mengalami peningkatan.

Peningkatan ivestasi terjadi terutama di jenis aset keuangan seperti di pasar modal. Martalena dan Maulinda (2011) mengatakan bahwa pasar modal (capital market) yang dikenal di Indonesia sebagai Bursa Efek Indonesia (BEI) merupakan pasar untuk 
berbagai instrumen keuangan jangka panjang yang bisa diperjual belikan, baik surat utang (obligasi), ekuitas (saham), reksadana, instrumen derivatif maupun instrumen lainnya. Pasar modal merupakan sarana pendanaan bagi perusahaan maupun institusi lain (misalnya pemerintah), dan sebagai sarana bagi kegiatan berinvestasi. Dengan demikian, pasar modal memfasilitasi berbagai sarana dan prasarana kegiatan jual-beli dan kegiatan terkait lainnya. Berdasarkan data operasional Bursa Efek Indonesia (BEI) dan data Kustodian Sentral Efek Indonesia (KSEI) mencatat jumlah investor baru pasar modal sampai dengan akhir Desember 2016 naik menjadi menjadi 535.994 SID dari sebelumnya 434.107 SID. Jumlah tersebut lebih besar dibandingkan pertumbuhan investor baru di tahun sebelumnya naik 18,83\% atau 68.804 SID dari posisi Desember 2014 sebanyak 365.303 SID. Data tersebut juga menyebutkan jumlah investor aktif per tahun juga mengalami peningkatan $21,35 \%$ atau 32.950 SID menjadi 187.268 SID di posisi akhir Desember 2016 dari 154.318 SID di Desember 2015.

Peningkatan pergerakan keaktifan investor tersebut juga diiringi fluktuasi saham. Saham-saham di Bursa Efek Indonesia sangat diminati karena memiliki kapitalisasi tinggi serta frekuensi perdagangan yang tinggi sehingga prospek pertumbuhan dan kondisi keuangan sangat baik namun demikian, karena investasi yang dilakukan menyangkut kelangsungan dan perkembangan saham, maka investor perlu mengetahui seberapa besar aset, modal dan keuntungan yang didapat oleh pemegang saham. Investor dalam berinvestasi di pasar modal sekurang-kurangnya perlu memperhatikan dua hal yaitu keuntungan yang diharapkan dan resiko yang mungkin terjadi menurut Sutrisno (2012). Investasi dalam bentuk saham menjanjikan keuntungan sekaligus resiko. Semakin besar return yang diharapkan, semakin besar pula peluang resiko yang terjadi. Oleh sebab itu pergerakan yang terjadi pada saham sangat tergambar jelas dalam fluktuasi return saham yang dipilihnya.

Return saham adalah pendapatan yang dinyatakan dalam persentase dari modal awal investasi. Pendapatan investasi dalam hal ini meliputi keuntungan jual beli saham. Return dapat berupa return realisasi yang sudah terjadi atau return ekspektasi yang belum terjadi tetapi yang diharapkan akan terjadi dimasa mendatang. Return realisasi (realized return) merupakan return yang telah terjadi. Return realisasi dihitung berdasarkan data historis. Return realisasi penting karena digunakan sebagai salah satu pengukur kinerja dari perusahaan. Return ekspektasi (expected return) adalah return yang diharapkan akan diperoleh oleh investor di masa mendatang. Berbeda dengan return realisasi yang sifatnya sudah terjadi, return ekspektasi sifatnya belum terjadi (Jogiyanto 2013)

Return saham adalah keuntungan yang diterima karena adanya selisih antara harga jual dengan harga beli saham dari suatu instrumen investasi. Return saham sangat tergantung dari harga pasar instrumen investasi yang berarti bahwa instrumen investasi harus diperdagangkan di pasar. Dengan adanya perdagangan, maka akan timbul perubahan nilai suatu instrumen investasi yang nantinya memberikan return saham. Besarnya return saham dilakukan dengan analisis return historis yang terjadi pada periode sebelumnya, sehingga dapat ditentukan besarnya tingkat kembalian yang diinginkan.

Fluktuasi return saham dialami oleh berbagai macam jenis saham termasuk salah satunya adalah sektor petambangan. Hal ini dibuktikan dengan pernyataan Co-Chairman Indonesian National Organizing, "Tanri Abeng" pada 02/03/2009, Selain itu, industri ini mengalami penurunan, namun dapat lebih bertahan dibandingkan dengan industri lainnya, hal ini terbukti saat terjadi krisis keuangan yang sempat melanda Indonesia, namun industri ini tidak terlalu parah terkena imbasnya. Sektor ini 
merupakan sektor unggulan karena Indonesia merupakan Negara yang kaya akan tambang dan salah satu pengekspor tambang terbesar.

Fenomena ini sangat menarik karena akan mempengaruhi keputusan yang akan diambil oleh investor. Investor bisa melihat hal yang menyebabkan penurunan tersebut salah satunya dilihat pada sisi kinerja perusahaan sebagai tolak ukur. Tolak ukur untuk mengukur kinerja perusahaan salah satunya adalah rasio profitabilitas, yakni rasio yang digunakan untuk mengukur efektifitas manajemen berdasarkan hasil pengembalian dari penjualan investasi serta kemampuan perusahaan menghasilkan laba (profit) yang akan menjadi dasar pembagian dividen perusahaan. Kinerja perusahaan terlihat dari tampilan laporan keuangan yang meningkat. Sehingga kondisi dan posisi keuangan akan mengalami perubahan. Dengan perubahan posisi keuangan ini, hal ini akan mempengaruhi return saham perusahaan.

\section{Teori Agensi}

Teori agency menjelaskan hubungan antara agent dan principal. Menurut Rebecca (2012) membuktikan bahwa teori agency adalah suatu hubungan yang timbul akibat adanya kontrak kepada pihak pemilik modal (principal) yang mendelegasikan pekerjaan dan agen (agent) sebagai pihak yang menerima pendelegasian pekerjaan, yang berarti terjadi antara kepemilikan dan kontrol perusahaan.

Pada agency theory yang disebut principal merupakan pihak yang memberikan perintah, mengawasi, memberikan penilaian dan masukan atas tugas yang akan dilakukan oleh agent, Sedangkan yang dimaksud dengan agent adalah pihak yang menerima dan menjalankan tugas sesuai kehendak principal. Ketika principal dan agent berkeinginan untuk dapat memaksimalkan kepentingan masingmasing, maka ada kemungkinan agent bertindak tidak untuk kepentingan principal. Principal berusaha untuk memaksimalkan laba (risk takers), sedangkan agent sebagai pelaksana aktivitas cenderung tidak menyukai resiko yang sangat besar (risk adverse). Untuk mengurangi konflik tersebut, maka principal perlu monitoring kinerja agent.

Hasil dari penelitian-penelitian yang dilakukan sebelumnya mendukung teori agency bahwa manajer bertindak untuk kepentingan pribadi dari pada perusahaan. Manajer melakukan hal tersebut karena adanya insentif atas pekerjaan mereka dan asimetri informasi dengan pemilik perusahaan. Menurut Sutiyok dan Rahmawati (2014) membuktikan bahwa dalam penyampaian laporan keuangan terdapat suatu asimetri informasi pada agent dan principal, agent memiliki informasi yang lebih banyak dibanding principal, karena agent hanya mengungkapkan sedikit mengenai laporan keuangan perusahaan.

\section{Teori Sinyal}

Teori kedua yang menjelaskan pentingnya pengukuran kinerja adalah teori signal (signalling theory). Teori signal membahas bagaimana seharusnya signalsignal keberhasilan atau kegagalan manajemen (agent) disampaikan kepada pemilik (principal). Teori signal menjelaskan bahwa pemberian signal dilakukan oleh manajemen untuk mengurangi informasi asimetris. Menurut Sari dan Zuhrotun (2006), teori signal (signalling theory) menjelaskan mengapa perusahaan mempunyai dorongan untuk memberikan informasi laporan keuangan kepada pihak eksternal. Dorongan tersebut timbul karena adanya informasi asimetris antara perusahaan (manajemen) dengan pihak luar, dimana manajemen mengetahui informasi internal perusahaan yang relatif lebih banyak dan lebih cepat dibandingkan pihak luar seperti investor dan kreditor.

Kurangnya informasi yang diperoleh pihak luar tentang perusahaan menyebabkan pihak luar melindungi diri dengan memberikan nilai rendah untuk perusahaan tersebut. 
Perusahaan dapat meningkatkan nilai perusahaan dengan mengurangi informasi asimetris, salah satu caranya adalah dengan memberikan signal kepada pihak luar berupa informasi keuangan yang dapat dipercaya sehingga dapat mengurangi ketidak pastian mengenai prospek perusahaan pada masa yang akan datang. Laporan tentang kinerja perusahaan yang baik akan meningkatkan nilai perusahaan.

Pada signalling theory, adapun motivasi manajemen menyajikan informasi keuangan diharapkan dapat memberikan signal kemakmuran kepada pemilik ataupun pemegang saham. Publikasi laporan keuangan tahunan yang disajikan oleh perusahaan akan dapat memberikan signal pertumbuhan deviden maupun perkembangan harga saham perusahaan.

\section{Return Saham}

Return saham merupakan pendapatan yang berhak diperoleh investor karena menginvestasikan dananya. Return memungkinkan investor untuk membandingkan keuntungan aktual ataupun keuntungan yang diharapkan yang disediakan oleh berbagai investasi pada tingkat pengembalian yang diinginkan. Seorang investor yang rasional akan sangat memperhatikan hasil pengembalian saham karena return saham merupakan salah satu indikator untuk mengetahui keberhasilan suatu investasi (Yocelyn dan Christiawan 2012).

Suatu tingkat pengembalian saham yang diharapkan atas investasi yang dilakukan beberapa kelompok saham melalui suatu portofolio yang disebut return saham. Menurut Hartono (2010) dalam Carlo (2014) menyatakan ada dua jenis return saham, yaitu return realisasi yang merupakan return yang telah terealisasi, yang dianalisis dengan dasar data historis, dan return ekspektasi merupakan yang diharapkan terjadi di masa depan.

Return Realisasi merupakan return yang telah terjadi dan telah dihitung berdasarkan data historis. Return realisasi sangat penting karena merupakan salah satu alat pengukuran perusahaan. Return realisasi ini juga dapat digunakan dalam penentuan return ekspketasi dan resiko di masa yang akan datang. Return ekspektasi adalah return yang diharapkan akan diterima oleh investor di masa yang akan datang (Alexander dan Destriana 2013).

Sedangkan expected return adalah return yang diharapkan akan diperoleh oleh investor di masa yang akan datang, jadi sifatnya belum terjadi. Perhitungan return ekspektasi dengan model pasar dilakukan dengan dua tahap, yaitu: (1) Dengan membentuk model ekspektasi dengan menggunakan data realisasi selama periode estimasi dan (2) Menggunakan model ekspektasi ini untuk mengestimasi return ekspektasi di periode jendela (Rosa dan Mulyani 2013).

\section{Return on Asset}

Return on Assets merupakan bagian dari analisis rasio profitabilitas. Return on Asset merupakan rasio antara laba bersih yang berbanding terbalik dengan keseluruhan aset untuk menghasilkan laba. Kasmir (2012) menjelaskan bahwa Return on Asset adalah rasio yang menunjukan hasil (return) atas jumlah aset yang digunakan dalam perusahaan. Dengan kata lain Return on Asset dapat didefinisikan sebagai rasio yang menunjukkan seberapa banyak laba bersih yang bisa diperoleh dari seluruh kekayaan yang dimiliki perusahaan. ROA merupakan indikator kemampuan sebuah unit usaha untuk memperoleh laba atas sejumlah aset yang dimiliki oleh unit usaha tersebut. Return on Asset mengukur kinerja operasi yang menunjukkan sejauh manakah aset dikaryakan. Rasio ini mengukur seberapa efektif perusahaan dalam memanfaatkan sumber ekonomi yang ada untuk menghasilkan laba.

Return on Asset merupakan pengukuran kemampuan perusahaan secara keseluruhan di dalam menghasilkan keuntungan 
dengan jumlah keseluruhan aset yang tersedia di dalam perusahaan. ROA digunakan untuk melihat tingkat efisiensi operasi perusahaan secara keseluruhan. Semakin tinggi rasio ini, semakin baik suatu perusahaan. Sebaliknya rasio yang rendah menunjukkan kemungkinankemungkinan sebagai berikut:

1. Adanya over investment dalam aset yang digunakan untuk operasi dalam hubungannya dengan volume penjualan yang diperoleh dengan aset tersebut.

2. Merupakan cermin rendahnya volume penjualan dibandingkan ongkos-ongkos yang diperlukan. Adanya inefisiensi baik dalam produksi, pembelian maupun pemasaran.

3. Adanya kegiatan ekonomi yang menurun

\section{Return on Equity}

Menurut Mursidah (2011) Return on Equity (ROE) merupakan rasio yang sangat penting bagi pemilik perusahaan (The Common Stockholder), karena rasio ini menunjukkan tingkat pengembalian yang dihasilkan oleh manajemen dari modal yang disediakan oleh pemilik perusahaan. ROE menunjukkan keuntungan yang akan dimiliki oleh pemilik saham. Adanya pertumbuhan ROE menunjukkan prospek perusahaan yang semakin baik karena berarti adanya potensi peningkatan keuntungan yang diperoleh perusahaan, sehingga akan meningkatkan kepercayaan investor serta akan mempermudah manajemen perusahaan untuk menarik modal dalam bentuk saham.

Rasio ini berguna untuk mengetahui efisiensi manajemen dalam menjalankan modalnya, semakin tinggi ROE berarti semakin efisien dan efektif perusahaan menggunakan ekuitasnya, dan akhirnya kepercayaan investor atas modal yang diinvestasikannya terhadap perusahaan lebih baik serta dapat member pengaruh positif bagi harga sahamnya di pasar. Return on Equity merupakan perbandingan antara laba bersih sesudah pajak dengan total ekuitas. Return on Equity merupakan suatu pengukuran dari penghasilan (income) yang tersedia bagi para pemilik perusahaan (baikpemegang saham biasa maupun pemegang saham preferen) atas modal yang mereka investasikan di dalam perusahaan (Harahap 2015).

Menurut Brigham dan Houston (2013), Return on Equity (ROE) merupakan rasio bersih terhadap ekuitas biasa mengukur tingkat pengembalian atas investasi pemegang saham biasa. Salah satu alasan utama perusahaan beroperasi adalah menghasilkan laba yang bermanfaat bagi para pemegang saham, ukuran dari keberhasilan pencapaian alasan ini adalah angka ROE berhasil dicapai. Semakin besar ROE mencerminkan kemampuan perusahaan dalam menghasilkan keuntungan yang tinggi bagi pemegang saham.

\section{Net Profit Margin}

Menurut Alexandri (2008) Net Profit Margin (NPM) adalah rasio yang digunakan untuk menunjukkan kemampuan perusahaan dalam menghasilkan keuntungan bersih setelah dipotong pajak. Menurut Brigham dan Houston (2013) Net Profit Margin adalah mengukur besarnya laba bersih perusahaan di bandingkan dengan penjualannya. Rasio ini menunjukkan berapa besar persentase laba bersih yang diperoleh dari setiap penjualan. Semakin besar rasio ini, maka dianggap semakin baik kemampuan perusahaan untuk mendapatkan laba yang tinggi.

Hubungan antara laba bersih sesudah pajak dan penjualan bersih menunjukkan kemampuan manajemen dalam mengemudikan perusahaan secara cukup berhasil untuk menyisakan margin tertentu sebagai kompensasi yang wajar bagi pemilik yang telah menyediakan modalnya untuk suatu resiko. Hasil dari perhitungan mencerminkan keuntungan netto per rupiah penjualan. Para investor pasar modal perlu mengetahui 
kemampuan perusahaan untuk menghasilkan laba.

\section{Return on Asset dan Return Saham}

Kasmir (2012) menjelaskan bahwa Return On Asset adalah rasio yang menunjukan hasil (return) atas jumlah aset yang digunakan dalam perusahaan. Dengan kata lain Return on Asset (ROA) dapat didefinisikan sebagai rasio yang menunjukkan seberapa banyak laba bersih yang bisa diperoleh dari seluruh kekayaan yang dimiliki perusahaan. Return on Asset mengukur kinerja operasi yang menunjukkan sejauh manakah aset dikaryakan. Rasio ini mengukur seberapa efektif perusahaan dalam memanfaatkan sumber ekonomi yang ada untuk menghasilkan laba. Semakin tinggi Return on Asset suatu perusahaan, semakin besar pula tingkat keuntungan yang dicapai oleh perusahaan. Return on Asset perlu dipertimbangkan oleh investor dalam berinvestasi saham, karena Return on Asset berperan sebagai indikator efisiensi perusahaan dalam menggunakan aset untuk memperoleh laba. Hipotesis sebagai berikut :

$\mathrm{H}_{1}$ Return on asset berpengaruh terhadap return saham

\section{Return on Equity dan Return Saham}

Menurut Brigham dan Houston (2013), Return on Equity (ROE) merupakan rasio bersih terhadap ekuitas biasa mengukur tingkat pengembalian atas investasi pemegang saham biasa. Angka ROE yang semakin tinggi memberikan indikasi bagi para pemegang saham bahwa tingkat pengembalian investasi makin tinggi. Hipotesis sebagai berikut:

$\mathrm{H}_{2}$ Return on equity berpengaruh terhadap return saham

\section{Net Profit Margin dan Return Saham}

Menurut Harahap (2011), semakin besar rasio ini semakin baik karena dianggap kemampuan perusahaan dalam mendapatkan laba. Semakin besar NPM, maka kinerja perusahaan akan semakin produktif, sehingga akan meningkatkan kepercayaan investor untuk menanamkan modalnya pada perusahaan tersebut. Rasio ini menunjukkan berapa besar persentase laba bersih yang diperoleh dari setiap penjualan. Semakin besar rasio ini, maka dianggap semakin baik kemampuan perusahaan untuk mendapatkan laba yang tinggi. Hipotesis sebagai berikut:

$\mathrm{H}_{3} \mathrm{Net}$ profit margin berpengaruh terhadap return saham

\section{METODE PENELITIAN}

Populasi yang akan menjadi pengamatan dalam penelitian ini adalah perusahaan pertambangan yang masih aktif dan terdaftar di Bursa Efek Indonesia (BEI) pada tahun 2013 sampai tahun 2017 yaitu sebanyak 13 perusahaan pertambangan. Teknik pengambilan sampel dilakukan dengan metode purposive sampling.

Sumber data dalam penelitian ini adalah data sekunder perusahaan-perusahaan yang terdaftar di BEI dan metode yang digunakan yaitu teknik pengumpulan data arsip (dokumen/copy). Data yang dikumpulkan berupa data laporan keuangan (financial statement) yang telah diaudit dan laporan tahunan (annual report) yang dikeluarkan oleh masing-masing perusahaan yang dipublikasikan di website resmi Bursa Efek Indonesia, yaitu www.idx.co.id.

Return saham merupakan hasil yang diperoleh dari menghitung selisih harga saham periode berjalan dengan periode sebelumnya dan mengabaikan deviden. Return on assets (ROA) digunakan untuk mengukur efektivitas perusahaan di dalam menghasilkan keuntungan dengan memanfaatkan aset yang dimilikinya. ROA diperoleh dengan cara membandingan antara net income after tax (NIAT) terhadap average total asset (Kusumawardani 2010). Return on equity merupakan salah satu cara untuk menghitung efisiensi perusahaan dengan 
cara membandingkan antara laba yang tersedia bagi pemilik modal sendiri dengan jumlah modal sendiri yang menghasilkan laba tersebut (Kusumawardani 2010).

Menurut Alexandri (2008) Net profit margin adalah rasio yang digunakan untuk menunjukkan kemampuan perusahaan dalam menghasilkan keuntungan bersih setelah dipotong pajak. Menurut Bastian dan
Suhardjono (2006) Net Profit Margin adalah perbandingan antara laba bersih dengan penjualan. Semakin besar NPM, maka kinerja perusahaan akan semakin produktif, sehingga akan meningkatkan kepercayaan investor untuk menanamkan modalnya pada perusahaan tersebut.

\section{HASIL PENELITIAN}

Hasil uji statistik deskriptif dan hipotesis dapat dilihat pada tabel berikut:

Tabel 1 Hasil Uji Statistik Deskriptif

\begin{tabular}{llllll}
\hline Variabel & N & Minimum & Maximum & Mean & Std Deviation \\
\hline Return_Saham & 65 & -24.70 & 24.00 & -3.3918 & 13.20110 \\
ROA & 65 & -8.72 & 16.25 & 4.9677 & 5.21926 \\
ROE & 65 & -10.62 & 26.74 & 6.5632 & 7.38565 \\
NPM & 65 & -9.62 & 21.48 & 6.5911 & 5.56106 \\
\hline
\end{tabular}

Tabel 2 Hasil Uji Hipotesis

\begin{tabular}{lll}
\hline Variabel & B & Sig. \\
\hline Constant & -5.814 & 0.024 \\
ROA & -1.435 & 0.003 \\
ROE & 0.658 & 0.025 \\
NPM & 0.794 & 0.027 \\
\hline
\end{tabular}

Return on asset mempunyai nilai $\mathrm{t}$ hitung sebesar $-3,078$ dengan nilai signifikansi sebesar 0,003 atau dibawah 0,05 maka dapat disimpulkan bahwa $\mathrm{H}_{1}$ diterima atau $\mathrm{ROA}$ berpengaruh terhadap Return Saham.

Return on Asset (ROA) merupakan pengukuran kemampuan perusahaan secara keseluruhan di dalam menghasilkan keuntungan dengan jumlah keseluruhan aset yang tersedia di dalam perusahaan. ROA digunakan untuk melihat tingkat efisiensi operasi perusahaan secara keseluruhan. ROA yang negatif disebabkan laba perusahaan dalam kondisi negatif (rugi) pula. Hal ini menunjukkan kemampuan dari modal yang diinvestasikan secara keseluruhan aset belum mampu menghasilkan laba. Penelitian ini didukung oleh Retna (2016), dan Sudarsono dan Sudiyanto (2016) bahwa ROA berpengaruh negatif terhadap Return Saham.

Sebagai contoh nyata adalah PT. Harum Energi Tbk yang mana peningkatan ROA menurunkan return saham. Berdasarkan data yang diberikan oleh Perusahaan tersebut bahwa, Dengan terus mewujudkan kinerja unggul, Perseroan telah memasarkan batubara kepada berbagai pelanggan baik di pasar domestik maupun di berbagai negara Asia 
seperti Jepang, Korea Selatan, Taiwan, Tiongkok dan India. Reputasi dalam memberikan kualitas terbaik membawa Perseroan pada berbagai penghargaan membanggakan. Di tahun 2012, Perseroan mendapatkan penghargaan 100 Best Companies in Indonesia dari Fortune Indonesia dan 200 Best Under a Billion dan Best Return on Investment dari Forbes Asia. Kemudian pada tahun 2013, Perseroan berhasil masuk dalam MSCI Global Small Cap Indices.

Di tengah masih melemahnya industri batubara global, Perseroan melaksanakan program pembelian kembali sahamnya di tahun 2015. Hal ini mencerminkan upaya Perseroan untuk menjaga kestabilan harga saham serta meredam sentimen pasar yang negatif selama tahun berjalan. Namun hasil yang dicapai malah sebaliknya bahwa harga saham tetap turun sehingga returnnya menurun akibat dari harga batu bara yang menurun lebih dominan mempengaruhi penurunanya.

Return on equity mempunyai nilai $t$ hitung sebesar 2,302 dengan nilai signifikansi sebesar 0,025 atau dibawah 0,05, maka dapat disimpulkan bahwa $\mathrm{H}_{2}$ diterima atau $\mathrm{ROE}$ berpengaruh terhadap return saham. Hasil penelitian ini sejalan dengan penelitian yang dilakukan oleh Nasrullah (2011), Martalita (2017) dan Michael (2014) menyatakan bahwa Return on equity mampu mempengaruhi return saham. Return on equity (ROE) dapat menjadi besar oleh karena labanya meningkat atau modalnya menurun (Wiagustini 2010). Hasil penelitian menunjukkan bahwa Return on equity berpengaruh terhadap return saham berarti Return on equity tinggi artinya prusahaan memiliki kemampuan yang baik dalam mengelola modal yang dimiliki sehingga dapat menghasilkan keuntungan penjualan yang tinggi dan pada dasarnya investor menyukai nilai return dari saham yang tercermin dalam besarnya ROE.
Net profit margin mempunyai nilai t hitung sebesar 2,265 dengan nilai signifikansi sebesar 0,027 atau dibawah 0,05 , maka dapat disimpulkan bahwa $\mathrm{H}_{3}$ diterima atau NPM berpengaruh signifikan terhadap return saham. Hal tersebut memberikan keyakinan terhadap para investor untuk memiliki saham perusahaan tersebut yang nantinya dapat meningkatkan return saham dimasa yang akan datang. Penelitian ini di dukung oleh Retna (2016), dan Martalita (2017).

\section{PENUTUP}

Berdasarkan hasil analisis menunjukkan bahwa return on asset, return on equity, dan net profit margin berpengaruh terhadap return saham. Return on asset berpengaruh negatif terhadap return saham. Return on equity dan net profit margin berpengaruh positif terhadap return saham perusahaan minning.

Penelitian ini di masa yang akan datang diharapkan dapat menyajikan hasil penelitian yang lebih berkualitas lagi dengan adanya beberapa masukan mengenai beberapa hal yang dapat menjadi acuan pembaharuan penelitian diantaranya:

1. Untuk penelitian selanjutnya, sebaiknya menambah variabel guna menyempurnakan penelitian ini.

2. Penelitian ini masih terbatas ruang lingkupnya pada perusahaan pertambangan. Hal ini menyebabkan jumlah sampel penelitian menjadi terbatas. Penelitian selanjutnya diharapkan menggunakan sampel yang lebih luas, dengan demikian, maka sampel menjadi lebih representative terhadap populasinya, serta hasil penelitian yang diperoleh akan lebih bermanfaat karena menunjukkan kecenderungan dari populasi yang ada. 


\section{REFERENSI:}

Alexandri, Moh. Benny. 2008. Manajemen Keuangan Bisnis. Cetakan Kesatu. Bandung: Alfabeta.

Alexander, N dan N. Destriana. 2013. Pengaruh Kinerja Keuangan Terhadap Return Saham. Jurnal Bisnis dan Akuntansi, 15(2), 123-132.

Bastian, Indra dan Suhardjono. 2006. Akuntansi Perbankan. Edisi 1. Jakarta: Salemba Empat.

Brigham, Eugene F. dan Joel F. Houston. 2013. Dasar-dasar manajemen keuangan Jilid 1 Edisi 11. Jakarta: Salemba Empat

Carlo, M. A. 2014. Pengaruh Return on Equity, Dividend Payout Ratio, dan Price to Earning Ratio Pada Return Saham. E-Jurnal Akuntansi Universitas Udayana, 7(1), 150-164.

Harahap, Sofyan Syafri. 2015. Analisis Kritis atas Laporan Keuangan. Edisi 1-10. Jakarta: Rajawali Pers.

Hartono, Parulian, Raymundus. 2009. "Analisis Hubungan Profitabilitas dengan Pergerakan Harga Saham pada Sektor Usaha Perbankan di Bursa Efek Indonesia". Journal of Applied Finance and Accounting. 2(2), 5166.

Jogiyanto. 2013. Teori Portofolio dan Analisis Investasi. Edisi Kedelapan. Yogyakarta: BPFE.

Kasmir. 2012. Analisis Laporan Keuangan. Penerbit: PT. Rajagrafindo Persada. Jakarta.

Kusumawardani, Angrawit. 2010. Analisis Pengaruh EPS, PER, ROE, FL, DER, CR, ROA Pada Saham dan Dampaknya Terhadap Kinerja Perusahaan LQ45 Yang Terdaftar di BEI Periode 2005-2009. Jurnal IImiah Ekonomi Bisnis, 19 (3), 16-22.

Martalena dan Maya Maulinda. 2011. Pengantar Pasar Modal, Bandung: Andi Yogyakarta

Mursidah, Nurfadilah. 2011"Analisis Pengaruh Earning Per Share, Debt to Equity Ratio dan Return On Equity terhadap Harga Saham PT UNILEVER INDONESIA Tbk", Jurnal STIE Muhamadyah Samarinda, 12 (1).

Nasrullah, Mokh Fariz. 2011. Pengaruh ROA (Return on Asset), ROE (Return On Equity), dan EAR (Equity to Asset Ratio) Terhadap Return Saham Pada Perusahaan LQ45 Periode 2006-2009. Skripsi. Malang: FE-UM.

Rosa, M dan E. Mulyani. 2013. Pengaruh Profitabilitas, OCF, dan EVA Terhadap Return Saham Perusahaan Manufaktur yang Terdaftar Di BEI. WRA 1(2), 219-242.

Rebecca, Yulisa dan Sylvia Veronica Siregar, 2012. Pengaruh Corporate Governance Index, Kepemilikan Keluarga, Dan Kepemilikan Insitusional Terhadap Biaya Ekuitas Dan Biaya Utang: Studi Empiris Pada Perusahaan Manufaktur Yang Terdaftar di BEl. Simposium Nasional Akuntansi. 15.

Retna, S. L. 2016. NPM, ROE, EPS Terhadap Return Saham Pada Perusahaan Farmasi Di BEI. Jurnal, IImu dan Riset Manajemen, 5(12).

Sari, Ratna Candra dan Zuhrotun. 2006. "Keinformatifan Laba di Pasar Obligasi dan Saham Uji Liquidation Option Hypothesis". Simposium Nasional Akuntansi 9. Padang.

Sutrisno, Edy. 2012. Manajemen Keuangan: Teori, Konsep, dan Aplikasi (Edisi Ke Delapan). Yogyakarta: Ekonisia

Sutiyok, dan Rahmawati, Evi. 2014."Pengaruh Mekanisme Corporate Governance terhadap Tingkat Kepatuhan Mandatory Disclosure Konvergensi IFRS di Perbankan. Jurnal Akuntansi dan Inventasi, 15(2), 152-162

Sudarsono, dan Bambang Sudiyanto. 2016, Faktor - Faktor Yang Mempengaruhi Return Saham Pada Perusahaan Property Dan Real Estate Yang Terdaftar Pada Bursa Efek Indonesia Tahun 2009 s/d 2014. Jurnal Bisnis dan Ekonomi, 23(1).

Wiagustini, Ni luh Putu. 2010. Dasar-Dasar Manajemen Keuangan. Denpasar. Udayana University Press.

Yocelyn, A dan Y. J. Christiawan. 2012. Analisis Pengaruh Perubahan Arus Kas dan Laba Akuntansi Terhadap Return Saham pada Perusahaan Berkapitalisasi Besar. Jurnal Akuntansi dan Keuangan 14(2), 81-90. 
